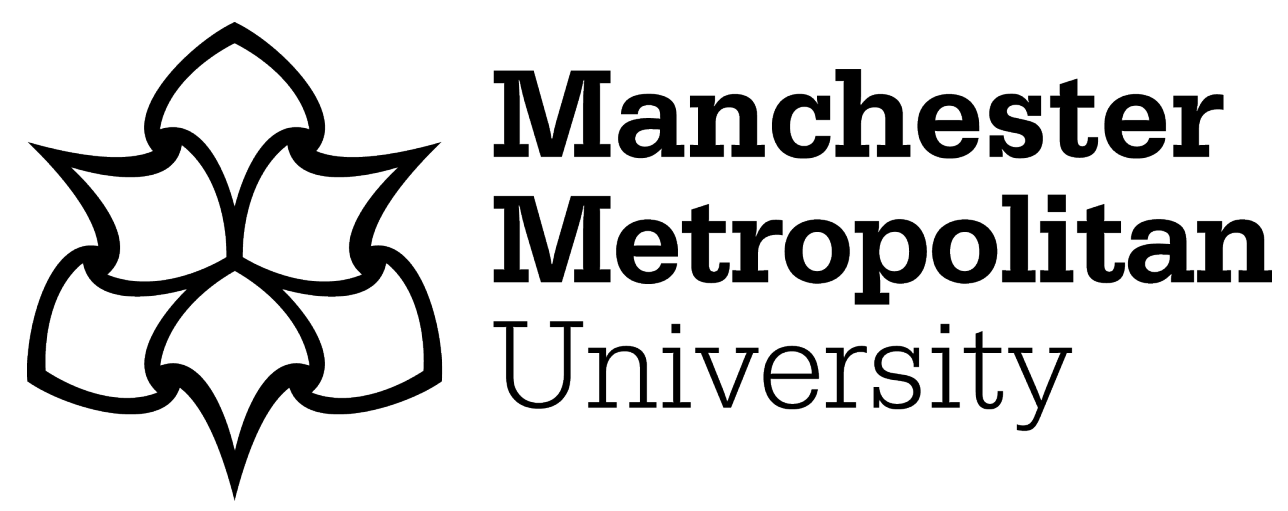

Whitton, NJ ORCID logoORCID: https://orcid.org/0000-0002-3085-5275 and Maclure, M ORCID logoORCID: https://orcid.org/0000-0001-7679-9240 (2017) Video game discourses and implications for game-based education. Discourse: studies in the cultural politics of education, 38 (4). pp. 561-572. ISSN 0159-6306

Downloaded from: https://e-space.mmu.ac.uk/600986/

Version: Accepted Version

Publisher: Taylor \& Francis

DOI: https://doi.org/10.1080/01596306.2015.1123222

Please cite the published version 


\title{
Video game discourses and implications for game-based education
}

\author{
Nicola Whitton* and Maggie Maclure
}

\begin{abstract}
Both of Manchester Metropolitan University, Education and Social Research Institute, Manchester, UK
\end{abstract}

\begin{abstract}
Increasingly prevalent educational discourses promote the use of video games in schools and universities. At the same time, populist discourses persist, particularly in print media, which condemn video games because of putative negative effects on behaviour and socialisation. These contested discourses, we suggest, influence the acceptability of games and limit critical analysis of their effectiveness as pedagogic tools. This article focuses on the representation of video games in media discourse. We present insights from a small-scale study of the construction of video game discourses in the UK print media in 2013, and discuss three areas that emerged. First, the assumptions inherent in the representation of the 'video game'; second, the implied lack of agency in the behaviour of 'the gamer'; and third, the way in which blame is manipulated. Finally, we consider the implications for game-based education.
\end{abstract}

Keywords: game-based learning; gamer; video gaming; media discourse; critical discourse analysis

\section{Video games in education: a brief overview}

This article explores representations of video games in the UK print media, and discusses the ways in which language is used to create narratives around the video game, the gamer, and the apportionment of blame. While we examine media interpretations of the links between video games and putative negative effects, such as violence or addiction, it is not the intention of this research to make judgments on the credibility or validity of these associations. Rather, we focus on how media depictions may carry implications for the uptake and development of approaches such as game-based learning in formal education.

There is a growing body of literature suggesting that computer games can be effective tools for learning (Connolly, Boyle, MacArthur, Hainey, \& Boyle, 2012; Perrotta, Featherstone, Aston, \& Houghton, 2013). There are numerous examples of the use of computer games for learning at all levels of childhood education, from early years (Sung, Chang, \& Lee, 2008), to primary school (Fisser, Voogt, \& Bom, 2012; Miller \& Robertson, 2010), and secondary levels (Huizenga, Admiraal, \& Akkerman, 2009;

\footnotetext{
* Corresponding author email: n.whitton@mmu.ac.uk
} 
Muehrer, Jenson, Friedberg, \& Husain, 2012). Cases can also be found in the literature on post-compulsory education, typically in scientific or technical areas (Coller \& Scott, 2009; Connolly, Stansfield, \& Hainey, 2007). While hundreds of case studies exist, there is a lack of robust systematic evidence of the value of games for learning in formal settings (Connolly et al., 2012) and much of the evidence is based on extrapolation from cases rather than substantial empirical studies underpinned by coherent theoretical frameworks (Klabbers, 2003). Some critics fear that celebration has tended to squeeze out critical engagement with wider socio-political and educational issues, producing in Buckingham's (2007) words 'a kind of fashionable superficiality' (p. 98).

Some advocates of game-based learning distinguish 'good' games from a much larger remainder; these 'well-designed' computer games have the power in principle to immerse learners in authentic environments and support them through meaningful activities (Brookes \& Moseley, 2012; Gee, 2007; Lankshear \& Knobel, 2003). They can provide engaging environments for problem-solving and meaning-making, and to create spaces for collaborative learning, both within and around the game. Gee (2003) suggests that good games are powerful learning vehicles because they 'are crafted in ways that encourage and facilitate active and critical learning and thinking ... [and] encourage reflective metatalk, thinking and actions in regard to the design of the game' (p. 46). The value of play in game spaces has also been identified as important from a pedagogic perspective, on the grounds that play is fundamental to the way in which human beings learn (Rieber, 1996) and provides opportunities to practise and make mistakes (Koster, 2005). While acknowledging the incompleteness of the evidence-base for computer game-based learning, we are going to assume that the theoretical potential is strong enough to merit critical engagement with some of the factors that may influence the design and uptake of educational gaming.

While, as we argue below, media influence may play a role in shaping attitudes and practices, there are many other potential barriers to the use of digital games for learning. Students may resist their introduction for diverse reasons, including differing degrees of game literacy, gendered preferences, or indeed a view that 'fun' is not compatible with learning (Bourgonjon, Valcke, Soetaert, \& Schellens, 2010). Such views of 'fun' may in turn reflect exposure to poorly-designed 'edutainment' games where gameplay is used as a reward for engagement with educational content (Buckingham \& Scanlon, 2004). Relatedly, the acceptability of play-based pedagogies may be limited by received notions about play as the province of young children and therefore unsuited to the serious business of later learning. Adult learners in particular may be less likely to find computer games intrinsically motivational and need to be convinced of their efficacy as a learning tool (Whitton, 2010). Teachers and policy makers also need to be convinced of the value and purpose of educational video games (Kebritchi, 2010; Kenny \& McDaniel, 2011) and be both willing and able to embrace the problem-solving, collaborative learning modes that gaming demands. Parents may feel caught between fear of the 'corrupting influence' of consumerism and a belief that its products might support their children's learning and self-expression (Buckingham, 2011, p. 74). When gaming goes to school, media representations thus become entangled in a complex and charged field that is already shaped by other discourses - pedagogical, developmental, psychological, professional and by affective ecologies of fear, desire, pleasure, and anxiety. 
Nevertheless, media representations of digital games and gaming form part of the interdiscursive fabric from which subjects construct their individual perceptions; such representations are often negative. Critical studies have noted, for example, dominant media discourses positing a link between video games and violence (Kearney \& Pivec, 2007), and the addictive qualities of computer games (Wood, 2007). These discourses permeate society and, it has been argued, influence the assumptions of teachers (Kenny \& McDaniel, 2011) and parents (Bourgonjon, Valcke, Soetaert, de Wever, \& Schellens, 2011). Such public perceptions, we contend, potentially limit the acceptability of approaches such as game-based learning in schools and other education settings.

An examination of how media discourses around gaming are constructed may provide some insight therefore into their possible influences on popular understandings of the phenomenon of video games, and help to promote a more expansive range of critical engagements with their educational potential. This might also help the game-based learning community to develop strategies to address common misapprehensions and move beyond hostile opposition. As an exploratory step in this direction, we undertook a small-scale study of representations of video games in the UK print media, focusing on discourses relating to video game play and the construction of the video gamer.

\section{A study of video game discourses in the UK press}

To better understand the ways in which the media construct notions of video games and video game players, we undertook a small-scale critical discourse analysis (CDA) of a selection of articles from the UK print media in 2013. CDA encompasses a range of approaches that are 'fundamentally interested in analyzing opaque as well as transparent structural relationships of dominance, discrimination, power and control as manifested in language' (Wodak \& Meyer, 2009, p. 10). According to Kress (1990), CDA brings an 'overtly political agenda' to the linguistic analysis of texts, with the aim of showing 'the imbrication of linguistic-discursive practices with the wider socio-political structures of power and domination' (p. 84). CDA is interested in how knowledge claims in texts are made and justified, and certain voices legitimated at the expense of others, in the construction of particular 'discursive realities' (Maclure, 2003). Language is seen therefore, not just as a representation of reality, but as a way of forming reality itself. CDA proceeds by 'denaturalizing the discursive practices and the texts of a society ... making visible and apparent that which may previously have been invisible and seemingly natural' (Kress, 1990, p. 85). Critical discourse analysis aims to not only change discursive practices, but also the institutional practices and structures that support these. Press and media constructions of social and political issues have been a major focus of critical discourse analysis (e.g. Fowler, 1991; Van Dijk, 1998). Such work has demonstrated, across a range of issues, how hegemonic opinions, interests and worldviews are legitimated, and how this is often accomplished in tacit or explicit opposition to a subordinated or stigmatised 'other'.

The data set used in this research were articles published in the UK print media in 2013 that, either directly or indirectly, contributed to the discourses around video games. We aimed to identify recurrent media discourses surrounding video games in a small 
selection of press articles, and consider the ways in which the media presented and constructed identities and value positions. We excluded articles that focused on either critiques of individual games (i.e. game reviews) or analysis of game development in order to ensure a focus on news, features and opinion articles relating to the effects of video games, rather than the industry or the games themselves. We took a sample of newspaper articles from four publications - the Daily Mail, Daily Telegraph, Daily Mirror, and Guardian. It was our intention to select publications that provided a mix in core readership with respect to socio-economic background and political orientation (both left- and right-leaning publications were represented).

We used the LexisNexus media search tool (www.lexusnexus.com), which provides full-text access to UK newspapers, to generate the data corpus. We carried out a full-text search of each of the four publications described above using the following search criteria:

Search terms: 'computer game' OR 'video game’ OR 'digital game’ Date: $\quad 1$ Jan 2013 to 31 Dec 2013

The initial search, based on these criteria, generated 1201 hits, and we then reviewed each article for suitability for inclusion in the final analysis. Articles focusing on the games industry or game reviews were removed (for reasons discussed previously), as were duplicate articles (for example, where two substantively identical articles appeared in two different editions of a publication). In order for us to select an article for inclusion, the story had to allude to the positive or negative effects of games, either directly or indirectly. In total, we selected 112 articles for the final analysis.

Our initial, thematic analysis involved highlighting the positive or negative effects identified in each article and grouping them into themes, such as those related to violence or addiction. Of the 112 articles reviewed, 18 articles (16\%) highlighted possible benefits of games, 27 (24\%) were neutral, and the majority, totalling 67 (60\%), constructed games in a negative light. Of these negatively-oriented examples, the prevailing argument focused on the link between violence in video games and violence in real life. A total of 23 articles $(21 \%)$ were on this theme, particularly in the context of children playing violent games. Other themes with relatively high numbers of articles (excluding those that centred on specific news stories such as Prince Harry's comments that likened war to playing a video game) included links to health risks (obesity, sleep disorders, back pain, cancer) and the potential for games to lead to addiction.

In contrast, the articles that focused on the benefits of games tended to be short and presented with an element of surprise, for example:

'don't despair if your child is hooked on Minecraft, as according to psychologists, it could actually be good for their development.' (Mail, 1 November 2013)

Such 'surprise' stories suggest that the default or 'unmarked' narratives of game-playing in the media are negative or cautionary.

Our analysis focuses primarily on three ways in which the articles construct the discourse of video games. First, we unpick the positioning of the 'video game', in 
particular looking at the concept of the ubiquitous game and the association between technology and moral decline. Second, we examine the construction of the 'video gamer', looking at the way that agency is withheld and the gamer situated as 'other'. Third, we discuss the discourse of 'video game violence' and, in particular, the use of implied causality and the over-emphasis on the game within the narrative of violence.

\section{Discourse of the video game}

Video games are various, with many different genres, ways of playing, hardware platforms, and models of collaboration, but this is not apparent in the media discourse. Discussion of the nuances and variety of video games was seldom present, leaving the implication that there is a single entity of 'the video game'. In this way the entire corpus of games are presented as equivalent, regardless of genre, style or content. The term 'video game' is used as a shorthand, generally for a negative characteristic; for example, lack of understanding of consequences in the real world:

'the "computer game" mentality of the trading floor.' (Guardian, 28 February 2013)

Similarly, there is the 'video-game style attack' (Mirror, 27 May 2013) and reference to 'video game style graphics' (Mail, 10 November 2013); both phrases make the assumption that video game interaction and style are homogeneous - the stereotypical image implied is of a violent first-person interaction. The use of 'video games' in this way as a convenient metaphor is not only ambiguous but also serves to continually reinforce the idea that most games involve extreme violence. This is simply not the case in recent years - in 1913 only 12\% of video games rated by the Entertainment Software Rating Board were rated as appropriate for over 18s only (ESA, 2014).

Another notable way in which the 'video game' is constructed is by association with other technologies; rather than being seen as a stand-alone entity, a game is frequently portrayed part of a larger spectrum of technology, and by implication part of a wider technologically-led moral decline. In this way, the author conceptually links 'harmful' technologies together, for example:

'... desensitised to the world due to computer games, TV and pornography.' (Mail, 18 December 2013)

'the number of children with sleep problems is being blamed on video games, mobile phones, televisions and computer consoles.' (Telegraph, 28 December 2013)

Video games players are thus, by implication, tainted by the association of technology and vice. There is little analysis or appreciation of differences between different types of technologies; playing video games is not addressed an activity in its own right, but as part of a continuum of technology misuse. Such in-depth analysis of difference is not characteristic of news genres, where polarization of ideological positions, and the establishment of 'ingroups' and 'outgroups' generally takes priority, ensuring that 'Our good things and Their bad things will tend to be emphasized' (Van Dijk, 2006, p. 124). It 
is interesting in this respect to note how the abject, gaming child in media representations is opposed, tacitly or explicitly to the 'normal and natural' child, who develops in line with deeply embedded 'common sense' assumptions. Technology is seen as a cause of stigma or anxiety, with the potential to knock a child off his or her natural developmental path. The 'child' is presented as innocent and defenceless in this discourse:

'if we are to examine current concerns we can find that they cohere largely around concerns about the vulnerability and suggestibility of young minds.' (Walkerdine, 1999, p. 5)

Video games, at least as represented in our sample, can then be constructed as part of a much broader narrative of technological evil that corrupts our innocent children. Logically, there is no real reason why natural or traditional should be intrinsically better than manufactured or technological; but the analysis of these articles shows the perpetuation of a long-standing anti-technology narrative that positions technology as necessarily 'bad' for children, and video games as part of the story.

\section{Discourse of the video gamer}

We identified several ways in which the media creates and propagates the narrative of the 'video game player', from the innocent child discussed previously to the mindless automaton. Throughout these constructions, there is the implication that players surrender their wills to those of the game and become devoid of agency. A common construction of video game players was as naïve innocents who are not in a position to make informed choices about their use of video games. Sometimes they are:

'impressionable teenagers unprepared for graphic depictions of torture, murder and sex.' (Mail, 25 September 2013)

Alternatively, they are simply passive consumers of technology, unable to make their own decisions:

'children are spending more time staring at screens than ever.' (Mirror, 8 January 2013)

In both of these scenarios, the implication is that the video game removes any agency that the child has to consider, or make informed decisions about, their video game use. This is closely linked to the construction of the video game player as addict. The question of whether video games are actually addictive in a medical sense is open to debate and it is not the intention of this paper to make a judgment in that area. Some researchers argue that addictive behaviours resulting from video game use could simply be a response to the powerful behavioural reinforcements present in games (Kutner \& Olson, 2008). Others contest that traditional models of addiction may not be appropriate for computerrelated activities, and that it is possible to distinguish between non-pathological highly engaged behaviours and pathological addiction in video game play (Charlton \& Danforth, 2010). 
Despite ongoing debates in the research literature, the language used in the selected articles typically make the unquestioning assumption that video games are addictive, and use terms that equate the use of games to the use of other known sources of addiction. For example, in an article on Candy Crush, a game that is described as 'highly addictive', players become 'hooked', and quitting is 'worse than smoking' (Mail, 17 October 2013). The language used around addiction paints a picture of players lost in their own realities, unable to deal with the real world:

'... children are battling the demons of addiction.' (Mirror, 21 April 2013)

'They can't cope and become addicted, reacting with tantrums and uncontrollable behaviour when they [games] are taken away.' (Telegraph, 22 April 2013)

Despite the research evidence suggesting that only a small minority of gamers might be considered to experience genuine addiction to game-playing (Kuss \& Griffiths, 2012) the media narrative is that this is a widespread phenomenon. This last example also highlights the way in which gamers are stereotyped as an homogenous group, and through the use of 'they', situated as an 'other' to the writer. This creates an 'us-andthem' dynamic in which authors position themselves in opposition to 'game players' and also implicitly assume a moral high ground and position of privilege.

This 'othering' of the gamer can be seen throughout the articles, but with the twist of authors taking the position of game expert. For example:

'Gamers can knife someone to death and then bring them back to life. Everything is reversible.'

(Mail, 27 January 2013)

Here, the journalist uses the term 'gamers' rather than, say, 'game players' to suggest a more deep involvement than simply being a player; anyone can play a game, but being a gamer implies a deeper transformation of identity. The text implies that these gamers have no conception of consequence. Yet games, by their very rule-based nature, have an extremely strong basis of cause-and-effect, action and consequence. However, this would not fit the grand narrative that gamers are irresponsible, taking risks almost at random, unsure of their positions in a half-real, half-imagined world:

'They don't understand the difference between reality and fiction because it's so graphical and real, and they do copy it.' (Mail, 18 September 2013)

Again, the player here is delineated clearly as distinct from the author, who makes sweeping generalisations, both about the nature of video games, and about the susceptibility of video game players. The discourse of the 'video game player' as being without agency in their decision-making is a troubling one, failing to take into account both the diversity of the players themselves and the games that they play. Rife with assumptions of addiction and passive consumption, this discourse succeeds in obfuscating the beneficial aspects of play: the power that games have to provide control, support learning, and create environments in which players have genuine agency. 


\section{Discourse of violence}

In the selected articles, authors made links between video games and violence in a variety of ways, and violent events are attributed to video games explicitly and implicitly, even when there was no evidence to support these links. A common technique was to generalise from the particular: to use the journalist's own experiences as a model for how everyone experiences the world. For example:

'I have seen so much film violence that I have, without noticing it, become desensitised. It is a shocking reminder that none of us is immune from the effects of screen violence.' (Mail, 16 August 2013)

Or, as in the example that follows, using the second person to imply a kinship between the writer and the reader, as part of a single humanity who all experience the world in the same way:

'It normalises extreme violence and cruelty, so the longer you play, the more you not only become inured to it, but start to find yourself gripped and even sickly amused by the action unfolding before your eyes.' (Mail, 18 September 2013)

In both cases, the outcome is the same: universal experience has been extrapolated from a single case, either the author's or the reader's. While the link between violence in video games and real life violence is still highly contested in academia, this does not stop journalists propagating the link in the media discourse. Typically, it is either implied, or highlighted beyond its actual significance. For example, after the killings of schoolchildren and teachers in Sandy Hook Elementary School, one author attempted to highlight the connection between the gaming habits of the killer and the massacre.

'Lanza, a recluse who spent hours playing the violent computer game Call of Duty, blasted his way into the school with a Bushmaster assault rifle he had taken from his mother's gun collection after murdering her in her bed.' (Mail, 29 March 2013)

The article did not address other reported details: for instance that Lanza was a very troubled young man, with serious mental health problems, who had access to an extensive array of weapons in a society where gun culture is accepted. In a later article, on a subsequent shooting, the following point was made:

'The AR-15 assault rifle that Alexis used is also one of the weapons in Call Of Duty. The game was also played by the Norway mass killer Anders Breivik.' (Mail, 18 September 2013)

In this quotation, there is a clear suggestion of a connection between a specific video game and two mass shootings; although in this example there is no evidence that one of the perpetrators even played the game. This quote misses two crucial points: first, Call of Duty contains hundreds of weapons, therefore mention of a specific model is hardly significant; and second, hundreds of thousands of young men have played this game at 
one time or another, yet most do not go on to commit mass murder. Again, the article resorts to the ready-to-hand, popular narrative of video games as incitements to real-life violence, rather than unpicking the complex and potentially troubling root causes of such tragedies.

In a further example of how links between video games and violence are overly emphasised, one story presented the headline:

'Accused was Xbox addict.' (Mirror, 1 March 2013)

The article relates, 'a man accused of murdering his pregnant ex-fiancée and unborn baby told a court how his video game and alcohol use caused tension at home'. It then goes on to document in detail how the couple fought about his use of video games, before disclosing towards the end of the piece that the perpetrator was a serious long-term alcoholic. While game playing might have been a contributory factor, there is a strong body of research linking alcohol to violence and aggression, yet this crucial factor does not make it into the headline because it does not fit within the grand narrative.

Similarly, an article with the headline:

'Driver ran over men like “computer game”.' (Telegraph, 1 November 2013)

This article describes 'an attack that was compared to a scene from a computer game', and explains that a witness, "who saw the attack, told Manchester Crown Court that he could "only describe it as unreal, a computer game like Grand Theft Auto" '. Apart from this analogy from the witness, there is no mention of computer games anywhere in the story, and no evidence anywhere that the attackers had ever played the game or been inspired by it. It is clear that the popular discourse of video games producing violence is the one that sells newspapers.

Playing violent video games is not always seen as negative; an article discussing Michael Adebolajo, one of the killers of Lee Rigby (Mirror, 24 May 2013) presents a curious alternative construction:

\footnotetext{
'Another former school pal revealed Adebolajo liked James Bond video games. He said: "Michael was as British as they come, but he's obviously got mixed up in the wrong crowd. He used to be a nice bloke. He loved playing 007 shoot-'em-ups on his Nintendo".'
}

In this case, playing a violent game is used as an example of Adeboajo's 'Britishness' rather than an indicator of his violent tendencies. Regardless of whether a link exists between playing violent video games and a propensity for violence, the assumptions and tenuous causality that the media frequently use as part of the debate cannot be helpful in facilitating a reasoned argument. It is clear that the popular discourse of video games producing violence accords with the orientation towards 'deviance and negativity' (Van Dijk, 1998) that structures and sells newspapers.

\section{Implications for game-based education}


The articles reviewed in this research show a leaning towards negative constructions of video games and gamers. If these are representative then these dominant discourses around video games may present a significant problem to researchers and practitioners in the field of games and learning. This is not to suggest that readers will necessarily accept media constructions uncritically. Public opinion is not monolithic, and readers are not empty vessels: as Morley (1980) noted in a ground-breaking study of responses to televised news:

The meaning of the text will be constructed differently according to the discourse (knowledge, prejudices, resistances, etc.) brought to bear upon the text by the reader and the crucial factor in the encounter of audience/subject and text will be in the range of discourses at the disposal of the audience. (p. 18)

Nevertheless, negative media images of gamers and gaming may have a particular impact, since many of those who encounter such images may not have direct experience of gaming, or contact with alternative, less negative discourses. Contrary to popular assumptions about the 'games generation' (Prensky, 2007) learners there are large numbers of young people who do not play with video games regularly, who are not motivated to learn with them for their own sake (Whitton, 2010). Teachers too, typically remain unconvinced that the use of games in education is worth the effort (Kenny \& McDaniel, 2011). We suggest two possible approaches to address perceptions of video games: first, a focus on education about games; and second, considering alternative approaches to games and learning that aim to remove the stigma of the 'video game' from the learning context.

A contributory factor to the discourse is the level of education about video games within the general population, or even in academia. Zagal (2010) argues that video games impact on our culture, how we socialise, and how we understand the world, and that games education, or ludoliteracy, is important for today's learners. Video game studies is a relatively new discipline, but one that is quickly growing and as research and prominence increases it will hopefully attract more into the field and increase its status. It is obvious to even the occasional gamer that many popular press articles on video games are written by people with limited knowledge of the field (or, more cynically, people who affect limited knowledge because it suits their readership).

The way in which all computer games are treated to be a single entity also makes it difficult to explain the nuances and diversities of different genres, platforms or and styles to someone who is not familiar with video games. The challenge is for the complex and nuanced academic literature on the subject to become accessible and relevant to a wider audience. Coupled with this, increased teacher education on digital games is key, not just for supporting the development of game-based learning, but in educating teachers to support their own students in understanding and interpreting the discourses and representations within the games themselves. Becker (2007) argues that -

... topics such as violence, game addiction and sex in games are all topics that regularly make headlines. If teachers are to be prepared to use games in the classroom, they must be aware of these issues and be prepared to address parental and administrative concerns in a reasonable way. (p. 483) 
The negative media positioning of games may present a real problem for teachers in relation to the use of game-based learning. The dominant discourses compound existing negative assumptions and make it increasingly difficult for games to be seen as a genuine and appropriate learning method. One strategy might be to change the words used in the context of games and learning, and the field of 'serious games' has emerged as a counter to the frivolous, violent games produced for entertainment. However, it has been argued that the value of play, to create safe spaces for exploration and practice, needs to be lauded and promoted rather than obscured within alternative terminology (Whitton, 2014).

An alternative approach is to focus on using games that differ from the stereotypical video game such as low-cost non-digital games, or the application of mechanics from games to educational settings, as is typical in gamification. The use of traditional games, such as board games or card games, in the classroom has a long history in education and has seen a recent resurgence (Moseley \& Whitton, 2013). Traditional games do not have many of the same associations as video games, and may be easier and cheaper for teachers, and indeed students, to develop for themselves. Other game forms such as alternate reality games, pervasive games or mobile games, which combine elements such as real-life treasure hunting and interactive storytelling, present alternative models.

Another way to look at the potential of video games in education is to view them, not as just teaching tools, but as pedagogic artefacts from which to learn. As noted earlier, it cannot be assumed that all games are equally promising from the point of view of innovative pedagogy. It may be necessary to identify 'good' digital games that embody techniques that support learning of various types (Gee, 2003). The study of games in order to determine the range of techniques they use, and how to apply them in learning and teaching, offers another potential way of using games in adult educational settings, and a positive challenge to the negative discourses often associated with video games. It is worth emphasizing however that teaching with video games will not per se ensure that learning takes place; our argument is that appropriately-designed games can provide powerful possibilities for learning. The educational context, pedagogic approach and acceptance by teachers, pupils and parents is crucial.

We must also acknowledge, in conclusion, that the introduction of game-based learning into educational settings is by no means uncontroversial even among educational researchers. Alongside the largely positive arguments that we have presented here, games-based learning has been criticized on a number of grounds: for instance that the open-endedness of digital games is illusory, since players are at all times subject to the algorithm that governs play; or that games promote the commodification of learning as the accumulation of rewards and penalties (Selwyn, 2013). Games-based learning is a site of contestation and polarised opinion, where techno-fear and techno-romanticism wage (often unproductive) battles. In this respect, the negativity that circulates in media discourses is but one reflection of this contested status. This makes it all the more necessary both to investigate in more detail the knowledge claims that circulate in media representations, and to understand how media discourse interacts with the other discourses that traverse the field of education. 


\section{References}

Becker, K. (2007). Digital game-based learning once removed: Teaching teachers. British Journal of Educational Technology, 38(3), 478-488.

Bourgonjon, J., Valcke, M., Soetaert, R., \& Schellens, T. (2010). Students' perceptions about the use of video games in the classroom. Computers \& Education, 54(4), 1145-1156.

Bourgonjon, J., Valcke, M., Soetaert, R., de Wever, B., \& Schellens, T. (2011). Parental acceptance of digital game-based learning. Computers \& Education, 57(1), 1434-1444.

Brookes, S., \& Moseley, A. (2012). Authentic contextual games for learning. In N. Whitton, \& A. Moseley (Eds.), Using games to enhance teaching and learning: a beginner's guide (pp. 91-107). New York, NY: Routledge.

Buckingham, D. (2007). Beyond technology: Children's learning in the age of digital media. Cambridge: Polity Press.

Buckingham, D. (2011). The material child. Growing up in consumer culture. London: Polity Press.

Buckingham, D., \& Scanlon, M. (2004). Connecting the family? 'Edutainment' web sites and learning in the home. Education, Communication \& Information, 4(2-3), 271-291.

Charlton, J., \& Danforth, I. D. W. (2010). Validating the distinction between computer addiction and engagement: online game playing and personality. Behaviour \& Information Technology, 29(6), 601613.

Coller, B. D., \& Scott, M. J. (2009). Effectiveness of using a video game to teach a course in mechanical engineering. Computers \& Education, 53(3), 900-912.

Connolly, T., Stansfield, M., \& Hainey, T. (2007). An application of games-based learning within software engineering. British Journal of Educational Technology, 38(3), 416-428.

Connolly, T., Boyle, E., MacArthur, E., Hainey, T., \& Boyle, J. M. (2012). A systematic literature review of empirical evidence on computer games and serious games. Computers \& Education, 59(2), 661686.

ESA. (2014). Essential facts about the computer and video game industry. Washington, DC: Entertainment Software Association.

Fisser, P., Voogt, J., \& Bom, M. (2012). Word Score: A serious vocabulary game for primary school underachievers. Education and Information Technologies, 18(2), 165-178.

Fowler, R. (1991). Language in the news: Discourse and ideology in the British press. London: Routledge.

Gee, J. P. (2003). What video games have to teach us about learning and literacy. New York, NY: Palgrave Macmillan.

Gee, J. P. (2007). Good video games plus good learning. New York: Peter Lang.

Huizenga, J., Admiraal, W., Akkerman, S., \& Dam, G. ten. (2009). Mobile game-based learning in secondary education: engagement, motivation and learning in a mobile city game. Journal of Computer Assisted Learning, 25(4), 332-344.

Kearney, P., \& Pivec, M. (2007). Sex, lies and video games. British Journal of Educational Technology, $38(3), 489-501$.

Kebritchi, M. (2010). Factors affecting teachers' adoption of educational computer games: A case study. British Journal of Educational Technology, 41(2), 256-270. 
Kenny, R. F., \& McDaniel, R. (2011). The role teachers' expectations and value assessments of video games play in their adopting and integrating them into their classrooms. British Journal of Educational Technology, 42(2), 197-213.

Klabbers, J. H. G. (2003). Interactive learning of what? In F. Percival, H. Godfrey, P. Laybourn, \& S. Murray (Eds.), The international simulation \& gaming yearbook, vol. 11 (pp. 257-266). Edinburgh: Napier University.

Koster, R. (2005). Theory of fun for game design. Scottsdale, AZ: Paraglyph Press.

Kress, G. (1990). Critical discourse analysis. Annual Review of Applied Linguistics, 11(1990), 84.

Kuss, D. J., \& Griffiths, M. D. (2012). Internet gaming addiction: A systematic review of empirical research. International Journal of Mental Health and Addication, 10(2), 278-296.

Kutner, L., \& Olson, C. K. (2008). Grand theft childhood. New York: Simon \& Schuster.

Lankshear, C., \& Knobel, M. (2003). New literacies: Changing knowledge and classroom learning. Philadelphia, PA.: Open University Press.

Maclure, M. (2003). Discourse in educational and social research. Milton Keynes: Open University Press.

Miller, D. J., \& Robertson, D. P. (2010). Using a games console in the primary classroom: Effects of 'Brain Training' programme on computation and self-esteem. British Journal of Educational Technology, 41(2), 242-255.

Morley, D. (1980). The 'nationwide' audience: Structure and decoding. London: BFI.

Moseley, A., \& Whitton, N. (2013). New traditional games for learning: a case book. New York: Routledge.

Muehrer, R., Jenson, J., Friedberg, J., \& Husain, N. (2012). Challenges and opportunities: using a sciencebased video game in secondary school settings. Cultural Studies of Science Education, 7(4), 783-805.

Perrotta, C., Featherstone, G., Aston, H., \& Houghton, E. (2013). Game-based learning: latest evidence and future directions. Slough: NFER.

Prensky, M. (2007). Digital Game-based Learning. St Paul, MN: Paragon House Publishers.

Rieber, L. (1996). Seriously considering play: Designing interactive learning environments based on the blending of microworlds, simulations, and games. Educational Technology Research and Development, 44(2), 43-58.

Selwyn, N. (2013). Distrusting educational technology: critical questions for changing times. London: Routledge.

Sung, Y.-T., Chang, K.-E., \& Lee, M.-D. (2008). Designing multimedia games for young children's taxonomic concept development. Computers \& Education, 50(3), 1037-1051.

Van Dijk, T. A. (1998). News as discourse. Hillsdale, NJ: Lawrence Erlbaum.

Van Dijk, T. A. (2006). Ideology and discourse analysis. Journal of Political Ideologies, 11(2), 115-140.

Walkerdine, V. (1999). Violent boys and precocious girls: regulating childhood at the end of the millennium. Contemporary Issues in Early Childhood, 1(1), 3.

Whitton, N. (2010). Learning with digital games. New York, NY: Routledge.

Whitton, N. (2014). Digital games and learning: research and theory. New York, NY: Routledge.

Wodak, R., \& Meyer, M. (2009). Discourse analysis: history, agenda, theory, and methodology. In R. Wodak, \& M. Meyer (Eds.), Methods for critical discourse analysis. London: Sage. 
Wood, R. T. A. (2007). Problems with the concept of video game 'addiction': Some case study examples. International Journal of Mental Health and Addiction, 6(2), 169-178.

Zagal, J. P. (2010). Ludoliteracy: defining, understanding and supporting games education. Pittsburgh, PA: ECT Press. 